\title{
Ефективність вживання вуглеводного напою перед ортопедичними хірургічними втручаннями у дітей
}

\author{
І. В. Кисельова, А. В. Біляев
}

Національна медична академія післядипломної освіти імені П. Л. Шупика, м. Київ

\section{Efficacy of the carbohydrate drink consumption before orthopedic surgical interventions in children}

\author{
I. V. Kyselova, A. V. Biliaiev \\ Shupyk National Medical Academy of Postgraduate Education, Kyiv
}

Реферат

Мета. Визначити вплив передопераційного вживання вуглеводного напою на метаболічні показники стресової відповіді на ортопедичні хірургічні втручання у дітей.

Матеріали і методи. У дослідній групі 30 дітей віком старше 1 року вживали напій, що містив 25 мг харчового вуглеводу мальтодекстрину на 100 мл води, за дві години до індукції анестезії. У контрольній групі 30 дітям призначали стандартне передопераційне голодування. Порівнювали концентрації глюкози, інсуліну, кортизолу у плазмі крові, індекси інсулінорезистентності та чутливості до інсуліну та наявність кетонових тіл у сечі після операції.

Результати. Перед операцією показники концентрації глюкози у плазмі крові в дослідній групі були вище, ніж у контрольній групі ( $\mathrm{p}=0,02)$. Наприкінці операції в дослідній групі були вище показники індексу чутливості до інсуліну ( $=0,01)$, нижче показники концентрації інсуліну у плазмі крові $(\mathrm{p}=0,008)$ та індексу інсулінорезистетності $(\mathrm{p}=0,01)$. У контрольній групі індекс інсулінорезистентності перевищував норму у 30\% хворих. Кетонові тіла в сечі в дослідній групі спостерігали у $20 \%$, в контрольній - у $50 \%$ хворих.

Висновки. Вживання вуглеводного напою за дві години до хірургічного втручання покращувало метаболічний профіль у дітей, яким виконували ортопедичні операції, та зменшувало прояви хірургічного стресу.

Ключові слова: мальтодекстрин; вуглеводи; дитяча хірургія; ортопедія; хірургічна стресова відповідь; швидке відновлення після хірургічного втручання; діти.

\section{Abstract}

Objective. The impact of preoperative consumption of carbohydrate drink on metabolic indices of the stress answer towards orthopedic surgical interventions in children was determined.

Materials and methods. In the investigated group 30 children, ageing more than one year, have consumed a drink, containing $25 \mathrm{mg}$ of the food carbohydrate maltodextrin on $100 \mathrm{ml}$ of water, two hours before the anesthesia induction. Standard preoperative starvation was administered to 30 children of a control group. There were compared the blood plasm concentrations of glucose, insulin, cortisol, and the insulin-resistance indices together with sensitivity towards insulin as well as the ketone bodies presence in urine after the operation.

Results. Preoperatively the indices of the glucose concentration in the blood plasm in the investigated group were higher, than in a control group $(p=0.02)$. At the end of the operations the sensitivity to insulin indices in the investigated group were higher $(p=0.01)$, the indices of insulin concentration in the blood plasm - lower $(p=0.008)$ as well as of the insulin-resistance index $(\mathrm{p}=0.01)$. In a control group the insulin-resistance index have exceeded the norm in $30 \%$ of patients. Ketone bodies in urine in the investigated group were observed in $20 \%$, while in a control one - in $50 \%$ of patients.

Conclusion. Consumption of a carbohydrate drink two hours before conduction of surgical intervention have improved a metabolic profile in children, in whom orthopedic operations were performed, and reduced the surgical stress signs.

Keywords: maltodextrin; carbohydrates; pediatric surgery; orthopedics; the surgical stress answer; rapid restoration after surgical intervention; children.

Розвиток стресу у відповідь на хірургічне втручання є природним захисним механізмом. Хірургічний стресце нейроендокринна реакція організму, яка проявляється складним поєднанням гормональних та метаболічних змін унаслідок одночасної дії декількох чинників: порушення цілісності тканин, крововтрати, маніпуляції на органах, болю. Ключовою ланкою метаболічних змін є поява резистентності тканин до інсуліну, підвищення в плазмі крові концентрації глюкози та вільних жирних кислот, прискорення катаболізму, наслідком чого є розвиток післяопераційних ускладнень [1]. Посилює хірургічний стрес передопераційне голодування, яке вважається стандартом анестезіологічного забезпечення. Навмисне чи ненавмисне голодування також запускає механізми метаболічної та імунної відповіді, що у свою чергу обумовлює стан катаболізму і підвищує резистентність тканин до інсуліну [2].

Вивчення механізмів стресової відповіді на хірургічне втручання привело до появи концепції «Fast-track surgery» - програми швидкого відновлення, яка уможливлює мінімізувати вплив негативних факторів та частоту розвитку ускладнень в хірургії [3]. Ця програма впроваджується вже близько 20 років у хірургічній практиці серед дорослих пацієнтів, проте ефективність іiі імплементації в педіатричній хірургії не вивчена, відповідні протоколи поки 
що застосовуються обмежено і потребують модифікації для успішної адаптації в педіатрії $[4,5]$.

Згадана програма складається 3 багатьох заходів, одним з яких є покращення метаболічного стану пацієнта в періопераційному періоді шляхом перорального прийому рідини, збагаченої вуглеводами, перед операцією. Це не лише запобігає небажаному зневодненню організму перед хірургічним втручанням, а й насичує його енергетичними субстратами та зменшує інсулінорезистентність $[1,6]$. Вживання вуглеводного напою за дві години до індукції анестезії є безпечним та рекомендовано Європейською та Американською спілками анестезіологів, а також Европейським товариством з клінічного харчування та метаболізму [7 - 9]. Як вуглевод, що міститься в складі таких напоїв, найчастіше використовують мальтодекстрин - продукт переробки крохмалю, який входить до складу багатьох звичайних продуктів харчування, у тому числі дитячого, а також застосовується у виробництві клінічного та спортивного харчування.

Мета дослідження: визначити вплив вжитого перед операцією вуглеводного напою на метаболічні показники стресової відповіді на ортопедичні хірургічні втручання у дітей.

\section{Матеріали і методи дослідження}

Проспективне дослідження щодо 60 дітей, яких готували до планових ортопедичних хірургічних втручань під загальною анестезією, схвалене етичним комітетом, проведено на базі Київської міської клінічної дитячої лікарні №1 протягом 2013 - 2017 рр. Критерії, за якими включали дітей до дослідження: вік старше одного року; фізичний стан, визначений за класифікацією ASA (Американської спілки анестезіологів) як I - II клас; тривалість хірургічного втручання більше однієї години. Критерії, на підставі яких дітей не включали до дослідження: невідкладні втручання; супутні ендокринні захворювання, патологія травного каналу, неможливість продуктивного контакту через затримку розвитку дитини; відсутність батьківського супроводу; відмова батьків від участі в дослідженні.

Усіх пацієнтів розподілили на дві групи: дослідну (n = 30) і контрольну (n=30). Вік пацієнтів коливався від 1 до 17 років (табл. 1). Хлопчиків було 37 (62\%), дівчаток - 23 (38\%): у дослідній групі - відповідно 19 (63\%) та 11 (37\%), у контрольній - відповідно 18 (60\%) та 12 (40\%).

Дитячий церебральний параліч мали 25 хворих, дисплазію кульшового суглоба - 22, поєднання обох діагнозів - 11 хворих. Серед інших захворювань були артрогрипоз, аномалії розвитку кінцівок, травматичні пошкодження кісток, гігроми та фіброми на кінцівках. Групи пацієнтів не відрізнялись за основними демографічними показниками (табл. 2), за тривалістю хірургічного етапу та анестезіологічного забезпечення були порівнянними. Фізичний стан, оцінений за класифікацією АСА як I клас, констатували у 12 (40\%) пацієнтів дослідної групи та у 15 (50\%) - контрольної, як II клас - відповідно у 18 (60\%) та 15 (50\%) пацієнтів.

3 усіма пацієнтами мав співбесіду анестезіолог перед оперативним втручанням. Увечері напередодні операції пацієнти обох груп їли й пили у своєму звичайному режи- мі. В день операції пацієнти дослідної групи за дві години до початку індукції анестезії вживали вуглеводний напій - розчин 25 мг харчового мальтодекстрину у 100 мл питної води - із розрахунку 5 мл/кг. Пацієнтам контрольної групи призначали стандартне голодування, але за бажанням вони могли вживати звичайну питну воду за дві години до початку індукції анестезії. Рутинної премедикації не проводили. Для індукції та підтримки анестезії внутрішньовенно вводили пропофол та фентаніл у рекомендованих вікових дозах. Перед інтубацією трахеї застосовували недеполяризуючі міорелаксанти. Інтраопераційно пацієнти отримували базову інфузію кристалоїдних розчинів - розчину Рінгера-лактатного з додаванням 5\% розчину глюкози з таким розрахунком, щоб концентрація глюкози у загальному інфузійному об'ємі становила 1\%.

Групи хворих порівнювали за показниками концентрації глюкози в крові натще під час госпіталізації, перед початком індукції анестезіі та наприкінці операції, а також за показниками концентрації кортизолу та інсуліну в крові, індексу інсулінорезистентності НОМА (Homeostasis Model Assesment) та індексу контролю чутливості до інсуліну QUICKI (Quantitative Insulin Sensitivity Check Index) по закінченні операції; порівнювали наявність кетонових тіл у сечі ввечері 1-ї доби після операції. Індекс інсулінорезистентності НОМА визначали за формулою:

НОМА = концентрація інсуліну в крові (мОд/л) $\times$

концентрація глюкози в крові (ммоль/л) / 22,5;

індекс QUICKI - за формулою:

QUICKI = 1/log інсуліну (мкОд/мл) $+\log$ глюкози (мг/л).

Дані опрацьовували статистично за допомогою ліцензійних програм Microsoft Excel 15.31 для Мас та StatPlus:mac 6.2.6.1. (AnalystSoftInc, 2017). Розподіл даних аналізували за критерієм Шапіро-Уілка. У разі нормального розподілу даних для порівняння середніх кількісних значень застосовували t-критерій Ст'юдента, ненормального - непараметричний критерій Манна-Уітні. Для порівняння залежних даних застосовували метод Вілкоксона, номінативних даних - критерій $\chi^{2}$ з поправкою Йєйтса і точний критерій

\begin{tabular}{|ccccc|}
\hline Tаблиця 1. & \multicolumn{3}{l|}{$\begin{array}{l}\text { Розподіл досліджуваних пацієнтів } \\
\text { за віковими групами }\end{array}$} \\
\hline \multirow{2}{*}{$\begin{array}{c}\text { Вікова група, } \\
\text { роки }\end{array}$} & \multicolumn{4}{c|}{ група пацієнтів } \\
\cline { 2 - 5 } & абс. & $\%$ & контрольна $(\mathrm{n}=30)$ \\
\hline $1-3$ & 3 & 10 & 3 & $\%$ \\
\hline $4-7$ & 6 & 20 & 6 & 20 \\
\hline $8-12$ & 9 & 30 & 8 & 27 \\
\hline $13-17$ & 12 & 40 & 13 & 43 \\
\hline
\end{tabular}

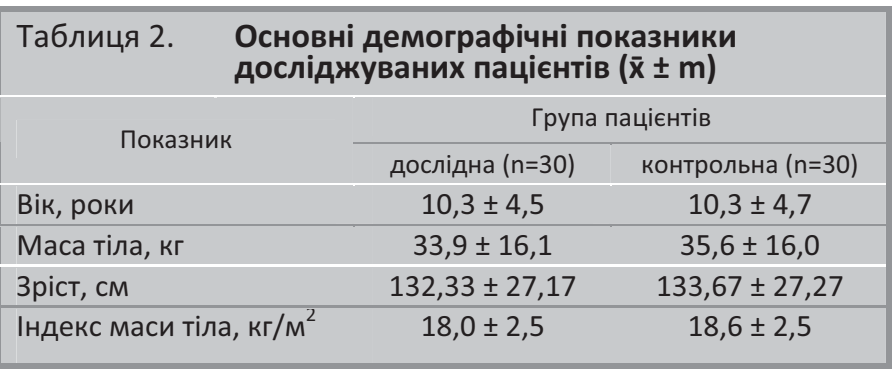




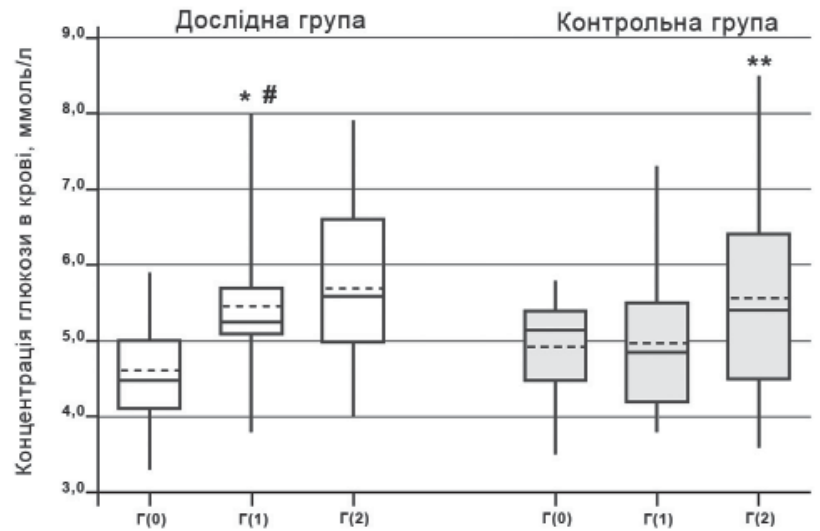

Динаміка змін концентрацї глюкози в крові натще - Г(О), перед індукцією анестезї Г( (1) та наприкінці операціӥ-Г(2). Примітка. Дані представлені якмедіана та інтервал між 25 та 75 квартілями, суцільна лінія всередині ящика - медіана, пунктир налінія - середнє значення, кінці вусів відповідають мінімальному та максимальному значенням; " - $<<0,001$ у порівнянні з концентрацією глюкози в крові натме у хворих дослідної групи; ${ }^{* *}$ - $p=0,03$ у порівнянні з концентрацією глюкози в крові перед індукиією анестезії у хворих контрольної групи; * - p=0,02 у порівнянні з концентрацією глюкози перед індукцією анестезї̈ у хворих контрольної групu.

Фішера. Різницю між показниками в групах вважали значущою, коли значення $\alpha$ були менше 5\% (p < 0,05).

\section{Результати}

Показники початкової концентрації глюкози в крові в обох групах не відрізнялись (див. рисунок). Проте перед індукцією анестезії концентрація глюкози в крові була вища в дослідній групі (p=0,02) у порівнянні з контрольною та в середньому на 20\% перевищувала початкове значення $(\mathrm{p}<0,001)$. У контрольній групі концентрація глюкози в крові перед індукцією анестезії не відрізнялась від початкового значення, а по закінченні операції зросла в середньому на 14\%. Наприкінці хірургічного втручання показники концентрації глюкози в крові в обох групах були порівнянними. Середні значення концентрації глюкози в крові залишались у межах норми в обох групах.

Концентрація інсуліну в крові наприкінці хірургічного втручання у пацієнтів дослідної групи становила (4,9 $\pm 3,3)$ мОд/л, контрольної - $(8,7 \pm 6,0)$ мОд/л $(p=0,008)$. Показники концентрації кортизолу в крові по закінченні операції не відрізнялись в обох групах.

Індекс інсулінорезистентності НОМА в дослідній групі дорівнював 1,24 \pm 0,98, контрольній - 2,26 2 2,04 (p= $0,01)$, індекс чутливості до інсуліну QUICKI - відповідно $0,39 \pm 0,04$ та 0,36 0,04 (p=0,01). У дослідній групі показники індексу НОМА перевищували референтне значення 2,6 у 2 (6,7\%) пацієнтів, а в контрольній - у 9 (30\%) пацієнтів (p=0,04). У аналогічної кількості хворих в обох групах індекс QUICKI перевищував референтне значення 0,331.

Кетонові тіла в сечі в 1-шу добу після операції в дослідній групі спостерігали у 6 (20\%) хворих, у контрольній - у 15 (50\%) хворих (p = 0,03). Кількість пацієнтів, у яких після операції виникли нудота та блювання, не відрізнялась в обох групах. Аспірації протягом усього анестезіологічного етапу не зафіксовано у жодного пацієнта в обох групах. Також жоден пацієнт дослідної групи не поскаржив- ся на порушення з боку травного каналу, нудоту або блювання в проміжку часу від моменту вживання вуглеводного напою до початку індукції анестезії.

\section{Обговорення}

Основна мета застосування вуглеводного напою перед хірургічним втручанням - зменшити негативні метаболічні зсуви, пов'язані з передопераційним голодуванням, які можуть посилювати хірургічну стресову відповідь організму. Відповідно ми досліджували саме ті показники, які відіграють роль у метаболічному профілі пацієнта та у формуванні метаболічної відповіді на хірургічне втручання.

Для оцінки вуглеводного стану дитини визначали концентрацію глюкози в крові безпосередньо перед початком індукції анестезії та по закінченні операції, на етапі гіпсування або накладання пов'язки, тобто перед пробудженням, та відстежували динаміку змін у порівнянні з початковим показником, визначеним натще під час госпіталізації. Результати дослідження показали, що у дітей через 2 год після вживання вуглеводного напою концентрація глюкози в крові зростала майже на 20\%, тоді як у дітей, які не отримували вуглеводного навантаження, концентрація глюкози в крові залишалась на рівні попередніх показників. Підвищення концентрації глюкози в крові можна пояснити екзогенним надходженням вуглеводів до організму. Щоб зменшити об'єм напою та запобігти примушуванню дитини пити, використовували 25\% розчин мальтодекстрину на відміну від усіх доступних у літературі досліджень, в яких вивчали ефективність 12,5\% розчину. Об'єми напою, які використовували для дорослих, ми вважали завеликими для дитини навіть у перерахунку на 1 кг маси тіла. На таку ж проблему вказують й інші автори [10].

У дорослих пацієнтів часто застосовують напій з мальтодекстрином двічі - 800 мл ввечері напередодні операції та 400 мл вранці перед операцією. Можливо, така тактика має сенс, коли планується втручання на травному каналі, та сприяє запобіганню зайвого призначення очищення кишечника перед хірургічним втручанням. У нашому дослідженні травний канал залишався інтактним, тому ми вважали недоцільним замінювати звичайне вечірнє харчування дитини, яке забезпечує нормальний калораж, на вуглеводний напій. У перехресному дослідженні на здорових волонтерах було доведено, що вуглеводне навантаження позитивно впливає на чутливість до інсуліну через 3 год після вживання карбогідратів і не чинить такого ж впливу на наступну добу [11].

Протягом хірургічного втручання діти в обох групах отримували базову інфузійну терапію, яка містила сольові розчини та 5\% розчин глюкози. В загальному об'ємі інтраопераційних інфузійних середовищ концентрація глюкози дорівнювала близько 1\% як у дослідній групі, так і в контрольній, що відповідає сучасним рекомендаціям періопераційної інфузійної підтримки у дітей [12]. Таким чином, вплив інфузійного розчину глюкози як екзогенного джерела вуглеводів не відрізнявся в обох групах. Проте динаміка концентрації глюкози в крові до початку хірургічного втручання та після його завершення у пацієнтів дослідної та контрольної груп була різною. В дослідній групі концентрація глюкози в крові залишалась без змін, що свід- 
чить про стабільність вуглеводного обміну протягом хірургічного втручання. В контрольній групі концентрація глюкози в крові наприкінці операції підвищувалась в середньому на 14\%. Тенденція до підвищення концентрації глюкози в крові протягом хірургічного втручання може вказувати як на ендогенний шлях надходження глюкози, так і на зниження чутливості тканин до інсуліну.

Створення ендогенної глюкози (шляхом глікогенолізу та глюконеогенезу) разом із появою резистентності до інсуліну вказує на природний захисний механізм, що розвивається у відповідь на пошкодження тканин. Для оцінки стресової реакції на хірургічне втручання визначали концентрацію інсуліну в крові наприкінці операції, а також розраховували індекси HOMA та QUICKI, які характеризують резистентність тканин до інсуліну.

Якщо концентрація глюкози в крові наприкінці хірургічного втручання не відрізнялась в обох групах, то концентрація інсуліну на цьому етапі була вірогідно нижче в дослідній групі, що можна пояснити підвищенням чутливості тканин до інсуліну після вуглеводного навантаження. На нашу думку, більш важливе значення у визначенні метаболічної стрес-девіації мають показники інсулінорезистетності тканин, ніж окремо взятий показник рівня інсуліну, оскільки вони відображають не тільки кількісні, а й функціональні характеристики цього гормону.

Найбільш точним способом визначення ступеня чутливості до інсуліну вважають еуглікемічний гіперінсулінемічний клемп-тест (ЕГК-тест). Але він занадто складний для застосування у рутинній клінічній практиці. Тому як альтернативу використовують математичні моделі визначення інсулінорезистентності. Індекси НOMA та QUICKI показали в дослідженнях високу діагностичну цінність, порівнянну з ЕГК-тестом [13]. Індекс НОМА в дослідній групі був нижчим, а індекс QUICKI - вищим, ніж у контрольній групі. Збільшення показників індексу НОМА аж до перевищення його референтного значення, а також знижені показники індексу QUICKI вказують на схильність до інсулінорезистентності у пацієнтів контрольної групи, яким, на відміну від дослідної групи, не призначали додаткового джерела надходження вуглеводів перед хірургічним втручанням. Результати щодо визначення інсулінорезистентності збігаються з даними мета-аналізів та систематичних оглядів досліджень у дорослих [6, 14] та одного дослідження, проведеного щодо дітей [15].

Порівнянням кількості хворих, у яких реєстрували кетонові тіла в сечі в ранньому післяопераційному періоді, встановлено, що в дослідній групі таких хворих було у 2,5 разу менше, ніж у контрольній групі. Кетонові тіла є результатом окислювання жирних кислот, коли ліпіди виступають у ролі джерела енергії як у разі голодування, так і у разі стресової реакціі, але у разі голодування в більшій мірі [16]. 3 іншого боку, коли в організмі дитини підтримується адекватний вуглеводний обмін, не посилюється розщеплення ліпідів з метою вироблення енергіï. Зменшення кількості пацієнтів з кетонурією в дослідній групі додатково свідчить про те, що пероральне вуглеводне навантаження перед операцією створює передумови для вибору організмом оптимального шляху вироблення енергії.

\section{Висновки}

1. Передопераційне голодування є одним з чинників, що посилюють стресову відповідь на хірургічне втручання.

2. Мальтодекстрин покращує метаболічний профіль, поповнюючи запаси вуглеводів в організмі та підвищуючи чутливість тканин до інсуліну у дітей під час ортопедичних хірургічних втручань.

3. Покращення метаболічного профілю приводить до зменшення проявів хірургічної стресової відповіді.

\section{References}

1. Nygren J, Thorell A, Ljungqvist O. Preoperative oral carbohydrate therapy. Curr Opin Anaesthesiol. 2015 Jun;28(3):364-9. doi: 10.1097/ ACO.0000000000000192

2. Rove KO, Edney JC, Brockel MA. Enhanced recovery after surgery in children: Promising, evidence-based multidisciplinary care. Paediatr Anaesth. 2018 Jun;28(6):482-92. doi: 10.1111/pan.13380.

3. Kehlet H, Wilmore DW. Multimodal strategies to improve surgical outcome. Am J Surg. 2002 Jun;183(6):630-41. PMID: 12095591

4. Pearson KL, Hall NJ. What is the role of enhanced recovery after surgery in children? A scoping review. Pediatr Surg Int. 2017 Jan;33(1):43-51. doi: 10.1007/s00383-016-3986-y.

5. Shinnick JK, Short HL, Heiss KF, Santore MT, Blakely ML, Raval MV. Enhancing recovery in pediatric surgery: a review of the literature. J Surg Res. 2016 May 1;202(1):165-76. doi: 10.1016/j.jss.2015.12.051.

6. Bilku DK, Dennison AR, Hall TC, Metcalfe MS, Garcea G. Role of preoperative carbohydrate loading: a systematic review. Ann R Coll Surg Engl. 2014 Jan;96(1):15-22. doi: 10.1308/003588414X13824511650614.

7. Smith I, Kranke P, Murat I, Smith A, O'Sullivan G, Soreide E, et al. Perioperative fasting in adults and children: guidelines from the European Society of Anaesthesiology. Eur J Anaesthesiol. 2011 Aug;28(8):55669. doi: 10.1097/EJA.0b013e3283495ba1.

8. Practice Guidelines for Preoperative Fasting and the Use of Pharmacologic Agents to Reduce the Risk of Pulmonary Aspiration: Application to Healthy Patients Undergoing Elective Procedures: An Updated Report by the American Society of Anesthesiologists Task Force on Preoperative Fasting and the Use of Pharmacologic Agents to Reduce the Risk of Pulmonary Aspiration. Anesthesiology. 2017 Mar;126(3):37693. doi: 10.1097/ALN.0000000000001452.

9. Braga M, Ljungqvist O, Soeters P, Fearon K, Weimann A, Bozzetti F. ESPEN Guidelines on Parenteral Nutrition: surgery. Clin Nutr. 2009 Aug;28(4):378-86. doi: 10.1016/j.clnu.2009.04.002.

10. Tudor-Drobjewski BA, Marhofer P, Kimberger O, Huber WD, Roth G, Triffterer L. Randomised controlled trial comparing preoperative carbohydrate loading with standard fasting in paediatric anaesthesia. $\mathrm{Br}$ J Anaesth. 2018 Sep;121(3):656-61. doi: 10.1016/j.bja.2018.04.040.

11. Svanfeldt M, Thorell A, Hausel J, Soop M, Nygren J, Ljungqvist O. Effect of "preoperative" oral carbohydrate treatment on insulin action-a randomised cross-over unblinded study in healthy subjects. Clin Nutr 2005 Oct;24(5):815-21. doi: 10.1016/j.clnu.2005.05.002.

12. Sumpelmann R, Becke K, Brenner S, Breschan C, Eich C, Hohne C, et al. Perioperative intravenous fluid therapy in children: guidelines from the Association of the Scientific Medical Societies in Germany. Paediatr Anaesth. 2017 Jan;27(1):10-8. doi: 10.1111/pan.13007.

13.Antuna-Puente B, Faraj M, Karelis AD, Garrel D, Prud'homme D, Rabasa-Lhoret R, et al. HOMA or QUICKI: is it useful to test the reproducibility of formulas? Diabetes Metab. 2008 Jun;34(3):294-6. doi: 10.1016/j.diabet.2008.02.001.

14. Li L, Wang Z, Ying X, Tian J, Sun T, Yi K, et al. Preoperative carbohydrate loading for elective surgery: a systematic review and meta-analysis. Surg Today. 2012 Jul;42(7):613-24. doi: 10.1007/s00595-012-0188-7.

15. Gawecka A, Mierzewska-Schmidt M. Tolerance of, and metabolic effects of, preoperative oral carbohydrate administration in children - a preliminary report. Anaesthesiol Intensive Ther. 2014 Apr-Jun;46(2):614. doi: 10.5603/AIT.2014.0013.

16. Biliaiev AV. Parenteral'noe i jenteralnoe pitanie v intensivnoj terapii. Kyiv: KIM; 2009. 344 p. [In Russian]. 